\title{
Variation of endophytic cork oak-associated fungal communities in relation to plant health and water stress
}

\author{
By B. T. Linaldeddu ${ }^{1,4}$, C. Sirca ${ }^{2,3}$, D. Spano ${ }^{2,3}$ and A. Franceschini ${ }^{1}$
}

\begin{abstract}
${ }^{1}$ Dipartimento di Protezione delle Piante, sezione di Patologia vegetale, Università degli Studi di Sassari, Via E. De Nicola 9, 07100 Sassari, Italy; ${ }^{2}$ DESA, Dipartimento di Economia e Sistemi Arborei, Università degli Studi di Sassari, Via E. De Nicola 9, 07100 Sassari, Italy; ${ }^{3}$ CMCC, Centro Euro-Mediterraneo per i Cambiamenti Climatici, divisione IAFENT, via E. De Nicola 9, 07100 Sassari, Italy; ${ }^{4}$ E-mail: ben@uniss.it
\end{abstract}

(for correspondence)

\begin{abstract}
Summary
The main objective of this study was to obtain more comprehensive knowledge about the effect of water stress on endophytic fungal communities in asymptomatic and declining cork oak trees. Six asymptomatic and six declining cork oak trees were randomly selected in a natural cork oak forest located in Sardinia, Italy. In February 2003, the soil around three asymptomatic and three declining trees was covered with a circular plastic film to reduce rain water supply with the intention to induce water stress. The remaining six trees served as controls. Predawn xylematic water potential (PWP) was used as water status indicator and measured seasonally. Between July 2003 and June 2004 fungal endophytes were isolated every 2-4 months from twigs, branches and woody tissues. Significant differences in PWP between covered and control trees were detected mainly in autumn. Gas exchange was greatest in asymptomatic control plants. All tissues were colonized by endophytic fungi. Nineteen fungal species were isolated from 1620 plant fragments. Biscogniauxia mediterranea was the most frequently isolated fungus. Its isolation frequency was significantly higher in declining covered trees than in control trees $(p<0.05)$. Presence of this fungus in asymptomatic control trees was significantly higher in winter than in summer. Water stress seems to reduce species diversity of the endophytic mycobiota in cork oak and to promote proliferation of some potentially pathogenic endophytes.
\end{abstract}

\section{Introduction}

Cork oak (Quercus suber L.) is a sclerophyllous evergreen tree species widespread in the Western Mediterranean area, where it plays an important ecological and socio-economical role. The climate of cork oak growing areas is characterized by warm to hot dry summers, cool wet winters, and unpredictable occurrence of rainfall and extreme events (Oliveira and Penuelas 2004; Cowling et al. 2005). Summer drought, associated with high temperatures, low water availability in the soil and high values of vapour pressure deficit, are the main factors limiting the distribution and biomass production of plants living in these environments (Bradford and Hsiao 1982; Larcher 2000; Sánchez-Gómez et al. 2006).

Evergreen species growing in Mediterranean areas have developed several molecular mechanisms for cell survival during drought periods (Kozlowski and Pallardy 2002; Wang et al. 2004), as well as biochemical and physiological adaptations responsible for low-temperature responsive genes (Novillo et al. 2004; Suping et al. 2005). Thus, cell damage is prevented and protection of photosynthetic function provided by a series of adaptive and constitutive mechanisms that are key factors for the growth of evergreen species in the Mediterranean areas, especially in summer and winter (Oliveira and Penuelas 2004; Cavender-Bares 2007; Varone and Gratani 2007).

In particular, cork oak has developed various physiological strategies for resistance to environmental stresses (Tenhunen et al. 1984; Oliveira et al. 1992; Faria et al. 1996). A strong link between stomatal closure, changes in soil water status and changes along the hydraulic pathway allows this species to maintain leaf water potential above the xylem cavitation threshold during the summer drought, ensuring an optimal use of water and carbon resources during low soil water availability (Otieno et al. 2007). Despite these adaptive mechanisms to environmental stresses, an increase in oak decline events and tree mortality, due to the effect of several adverse abiotic and biotic factors and attack by various endophytic fungal pathogens, has been detected in many Mediterranean countries during past decades (Luque and Girbal 1989; David et al. 1992; Bakry and Abourouh 1995; Santos 1995; Gallego et al. 1999; Sánchez et al. 2003; Linaldeddu et al. 2007a). Environmental stresses such as low or high temperatures, drought, high irradiance, and lack of some soil nutrients may lead to physiological plant modifications and influence the plant susceptibility to fungal pathogens (Schoeneweiss 1975; Boyer 1995; Garrett et al. 2006). The endophytic microbial component of oak trees is reactive to host changes due to adverse environmental factors; in particular, several fungal endophytic pathogens appear to be involved in the rapid decline of stressed oak trees (DesprezLoustau et al. 2006; Gonthier et al. 2006). Endophytic fungal communities include both mutualistic and pathogenic species (Carroll 1988; Redman et al. 2001; Mucciarelli et al. 2003; Ragazzi et al. 2003; Sieber 2007). Pathogenic fungi can persist in a latent phase in asymptomatic tissues for a certain period of time or until the onset of plant stress (Linaldeddu et al. 2005a; Slippers and Wingfield 2007).

The results of recent studies carried out in Southern Italy have highlighted Biscogniauxia mediterranea (De Not.) 0. Kuntze, Botryosphaeria corticola Phillips, Alves et Luque, Discula quercina (Westend.) Arx and Pleurophoma cava (Schulzer) Boerema, Loer. \& Hamers as the main endophytic species involved in the aetiology of oak decline (Anselmi et al. 2004). All of these 
species are able to latently colonize all canopy cork oak tissues, but also cause cankers, dieback and an imbalance of some metabolic processes including stomatal conductance and photosynthesis (Luque et al. 1999, 2000; Franceschini et al. 2005; Linaldeddu et al. 2009). Since only limited information about cork oak-endophytic pathogen relationships under drought conditions in the field is available, the aim of this study was to obtain more comprehensive knowledge about the temporal variation of endophytic fungi associated with cork oak trees in relation to plant health and water stress.

\section{Materials and methods}

\subsection{Site description and experimental design}

The study was carried out in a natural cork oak forest 'Foresta Demaniale Monte Pisanu' located in Sardinia, Italy ( $40^{\circ} 26^{\prime} \mathrm{N}$, $8^{\circ} 58^{\prime} \mathrm{E}, 820 \mathrm{~m}$ a.s.l.). The mean annual temperature is $11.4^{\circ} \mathrm{C}\left(\min 5.9^{\circ} \mathrm{C}\right.$, $\max 16.5^{\circ} \mathrm{C}$ ), and the mean annual rainfall is $610.2 \mathrm{~mm}$ (data from the period 1995-2004). The vegetation of the whole area is mainly composed of downy oak (Quercus pubescens Willd.), growing in some parts alongside cork oak and holm oak (Quercus ilex L.). Large forest areas are covered by cork oak without the other two species. Inside one area covered almost exclusively by cork oak, 12 mature cork oak trees (six asymptomatic and six declining) were randomly selected. To reduce rainfall water supply and to increase the level of water stress through the reduction in the soil water content, from February 2003 the soil around six of the selected cork oak trees (three asymptomatic and three declining) was covered under the crown projection by a circular plastic film structure $\left(70 \mathrm{~m}^{2}\right)$, about $0.6 \mathrm{~m}$ above the soil (Fig. 1). Moreover, the tree trunk in correspondence with the roof was sealed by polyurethane glue, and a trench in correspondence with the roof border was made. The other selected trees (three asymptomatic and three declining) were used as a control. Weather data was provided by a meteorological station located near the experimental site by the Regional Agency for the Environmental Protection of Sardinia.

\subsection{Ecophysiological measurements}

During the period July 2003-June 2004, the predawn xylematic water potential (PWP) was measured seasonally. Three 3-yearold twigs from each of the 12 examined cork oak trees were enclosed in a plastic bag, cut and PWP was then immediately measured by an electronic pressure chamber (SKPM 1400; SKYE Instruments, Llandrindod Wells, UK). At the same time, one soil core of $5 \mathrm{~cm}$ diameter and $40 \mathrm{~cm}$ depth was sampled below each tree and the soil moisture content was measured by gravimetric method.

In June 2004, leaf gas exchange was measured as net photosynthesis (Pn) $\left(\mu \mathrm{mol} \mathrm{CO}_{2} \mathrm{~m}^{-2} \mathrm{~s}^{-1}\right)$, transpiration $(\mathrm{E})$ (mmol H $\mathrm{H} \mathrm{m}^{-2} \mathrm{~s}^{-1}$ ) and stomatal conductance $\left(\mathrm{g}_{\mathrm{s}}\right)\left(\mathrm{mmol} \mathrm{H}_{2} \mathrm{O} \mathrm{m}^{-2} \mathrm{~s}^{-1}\right)$ rates, using a semi-portable infrared gas analyzer (ADC model 2250; Analytical Development Company, Hoddesdon, UK) equipped with a Parkinson's leaf cuvette, on four mature leaves chosen at random from each of the 12 selected trees. Measurements were made at 11:00 am using artificial light with a photosynthetically active radiation (PAR) value near $1600 \mu \mathrm{mol} \mathrm{m}^{-2} \mathrm{~s}^{-1}$. Air flux through the chamber was adjusted to $3.33 \mathrm{ml} \mathrm{s}^{-1}$.

\subsection{Isolation and identification of fungal taxa}

Since July 2003 fungal endophytes were seasonally isolated from three 1-year-old twigs, three 3-year-old branches and three cylindrical wood cores ( $5 \mathrm{~mm}$ diameter) extracted with a Pressler incremented borer from the trunk of each of the 12 selected trees. All samples were first superficially sterilized through immersion for 15 min in $10 \% \mathrm{H}_{2} \mathrm{O}_{2}$ and subsequently rinsed five times in sterile water. The surface sterilization was carried out in accordance with a method tested by Ragazzi et al. (2003), Franceschini et al. (2005) and Gonthier et al. (2006). Next, all samples were left to dry on sterile filter paper under aseptic conditions. Three fragments of bark of about 3-4 $\mathrm{mm}^{2}$ were taken from each twig and branch, while three fragments of

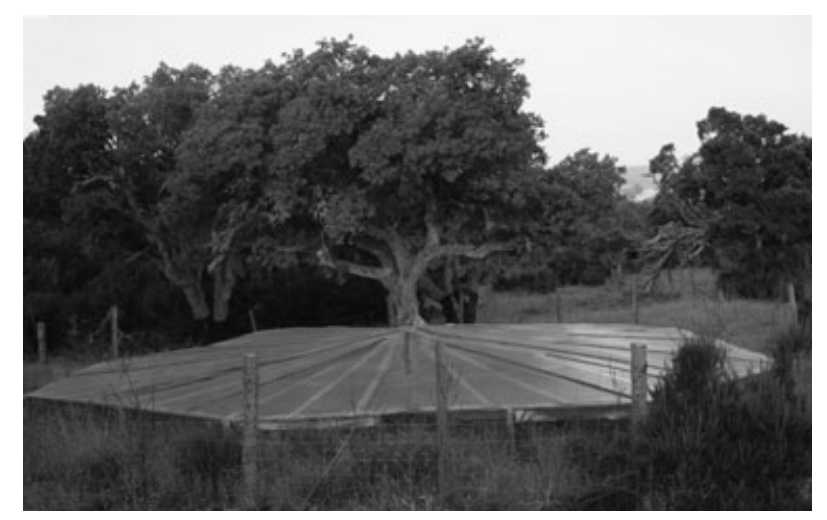

Fig. 1. Cork oak tree with its root zone covered by a plastic roof for rainfall interception. 
5-6 $\mathrm{mm}^{3}$ were obtained from each wood core. All samples were placed in Petri dishes containing potato dextrose agar (PDA; Fluka, Sigma-Aldrich, Milano, Italy) amended with $0.06 \mathrm{~g} \mathrm{l}^{-1}$ of streptomycin to limit the development of bacterial colonies. All inoculated dishes were transferred to a thermostat at $25^{\circ} \mathrm{C}$ and left in the dark for 5 days. Then the mycelium of each colony was again transferred to a Petri dish with PDA and incubated at $25^{\circ} \mathrm{C}$ until differentiation of the reproductive structures. To facilitate the formation of asexual or sexual reproductive structures necessary for taxonomic identification, fungal isolates were sub-cultured on PDA dishes with sterile cork oak twig fragments. Morphological and cultural features (conidial pigmentation, wall texture, number of septa, size and shape as well as mycelial growth rate) were used to identify fungal isolates using appropriate taxonomic keys (Sutton 1980; Pitt 1991; Ellis and Ellis 1997; Boerema et al. 2004; Phillips et al. 2005). Representative isolates of all endophytic species obtained in this study were stored in the culture collection of the Department of Plant Protection, University of Sassari.

\subsection{Colonization rate and isolation frequency}

For each plant the rate of endophytic colonization (CR) was calculated using the formula:

$\mathrm{CR}=N_{\mathrm{c}} / N_{\mathrm{t}} \times 100$

where $N_{\mathrm{c}}$ represents the number of segments colonized by at least one fungal species, and $N_{\mathrm{t}}$ is the total number of segments examined.

The isolation frequency (IF) of a single endophyte taxon was defined by the following formula:

IF $=N_{\mathrm{i}} / N_{\mathrm{t}} \times 100$

where $N_{\mathrm{i}}$ and $N_{\mathrm{t}}$ are the number of segments colonized by the endophyte and the total number of segments examined, respectively.

\subsection{Diversity of endophytic communities}

The structure of the endophytic community was assessed by two indices:

Shannon's diversity index $(H)$ :

$H=-\sum p_{\mathrm{i}} \ln p_{\mathrm{i}}$

and Simpson's dominance index $(D)$ :

$D=\sum p_{\mathrm{i}}^{2}$

where $p_{\mathrm{i}}$ is the relative abundance of $\operatorname{taxon}_{\mathrm{i}}$.

The dominance index ranges from 0 (all taxa are equally frequent) to 1 (the 'community' consists of only one taxon). Calculations were done using the freeware package past version 1.89 (http://folk.uio.no/ohammer/past) (Hammer et al. 2001).

\subsection{Statistical analysis}

All experimental data (CR, IF, predawn xylematic water potential and leaf gas exchange values) were subjected to analysis of variance (ANOVA). Means were compared by the least significant difference (LSD) test at $\mathrm{p}=0.05$, using xlstat software (Addinsoft, France). Percentage data were angular transformed before analysis.

\section{Results}

\subsection{Meteorological data}

The trend of air and dew temperature, and rainfall during the years 2003 and 2004 is shown in Fig. 2. In the year 2003, characterized throughout Europe by an exceptional heat wave, the mean annual temperature in the experimental site was $12.1^{\circ} \mathrm{C}\left(+0.7^{\circ} \mathrm{C}\right.$ with respect to the climatic value $)$; in addition, minimum and maximum annual values of air temperature recorded during 2003 were significantly higher than the climatic data $\left(+0.3^{\circ} \mathrm{C}\right.$ and $+0.7^{\circ} \mathrm{C}$, respectively). In 2004 , mean annual values of air temperature were in accordance with the climatic values. The heat wave of 2003 caused a remarkable increase in the atmosphere evapotranspirative demand, also highlighted by the gap between air and dew temperatures. Annual rainfall values both in 2003 and 2004 were significantly higher than climatic data $(+237.8 \mathrm{~mm}$ and $+166.6 \mathrm{~mm}$, respectively).

\subsection{Predawn xylematic water potential}

Reduction of rainfall water supply due to plastic covers caused a distinct decrease in the soil moisture content of covered trees (Fig. 3). The PWP values alternated between the covered and uncovered trees throughout the study. In July 2003, no significant differences in the PWP values between covered and uncovered asymptomatic trees were detected, whereas the PWP values were significantly lower in declining uncovered trees than in those which were covered (Table 1). In autumn (October and December 2003), the PWP values were lower in covered asymptomatic and declining trees than in uncovered ones. No significant differences in PWP values were detected between declining covered and uncovered trees, and between 


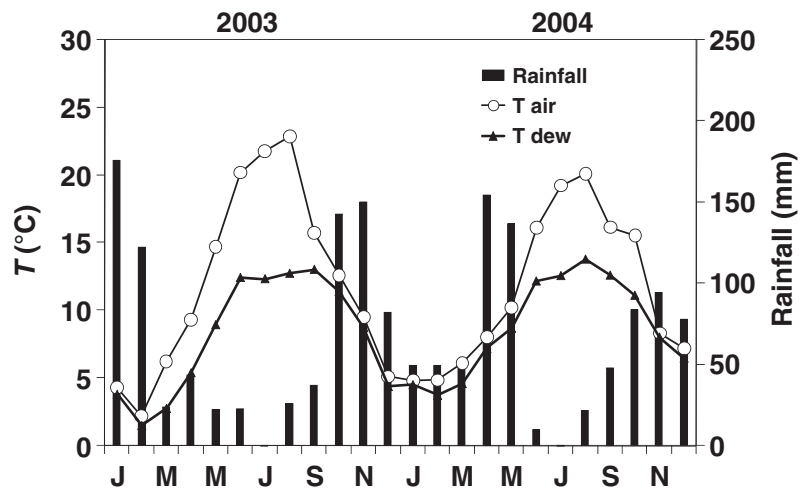

Fig. 2. Mean monthly air and dew temperatures, and monthly rainfall values recorded during the experimental period.

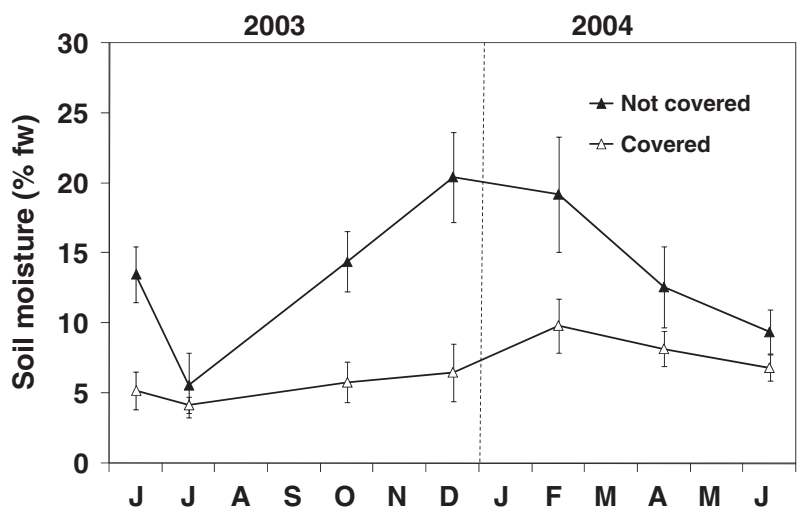

Fig. 3. Mean soil moisture values in covered and not covered (control) plots. Bars represent standard deviation.

Table 1. Mean predawn xylematic water potential (PWP) values (MPa) of examined cork oak trees measured during the experimental period.

\begin{tabular}{|c|c|c|c|c|c|c|}
\hline \multirow[b]{2}{*}{ Treatment group } & \multicolumn{6}{|c|}{ Period } \\
\hline & July 2003 & October 2003 & December 2003 & February 2004 & April 2004 & June 2004 \\
\hline DC & $-1.234 \mathrm{a}$ & $-0.903 c$ & $-0.200 \mathrm{~b}$ & $-0.255 b$ & $-0.340 \mathrm{a}$ & $-0.364 a$ \\
\hline $\mathrm{HC}$ & $-1.319 a b$ & $-0.804 \mathrm{bc}$ & $-0.270 \mathrm{c}$ & $-0.143 a$ & $-0.410 \mathrm{~b}$ & $-0.525 b$ \\
\hline DNC & $-1.505 c$ & $-0.700 \mathrm{ab}$ & $-0.102 \mathrm{a}$ & $-0.228 b$ & $-0.397 a b$ & $-0.449 \mathrm{ab}$ \\
\hline HNC & $-1.384 b c$ & $-0.673 a$ & $-0.121 \mathrm{a}$ & $-0.212 b$ & $-0.397 a b$ & $-0.452 \mathrm{ab}$ \\
\hline
\end{tabular}

asymptomatic covered and uncovered trees in the measurements taken in February, April and June 2004 except for the asymptomatic group in February 2004, when the PWP mean value of covered trees was significantly higher.

\subsection{Gas exchange measurements}

A summary of gas exchange measurements, made 16 months after starting the drought treatment, is shown in Table 2. The net photosynthetic values (Pn) ranged from 2.4 to $12.2 \mu$ mol $\mathrm{CO}_{2} \mathrm{~m}^{-2} \mathrm{~s}^{-1}$. The leaf transpiration rate (E) ranged from 1.2 to $4.2 \mathrm{mmol} \mathrm{H} \mathrm{O} \mathrm{m}^{-2} \mathrm{~s}^{-1}$. Average net photosynthetic and transpiration rates were significantly higher in the non-covered asymptomatic control trees than in the other three treatments, indicating a better physiological status. With respect to stomatal conductance $g_{s}$, the highest mean values was observed in the asymptomatic control trees.

\subsection{Endophytic infections}

Fungal endophyte infections were detected in all examined cork oak tissues (Fig. 4). Significant differences in the colonization rate of cork oak trees were detected among the sampling periods and treatments (Table 3). In particular, the highest values of CR were observed between February and June 2004 in the declining covered trees. 
Table 2. Mean $( \pm \mathrm{SE})$ value of net photosynthesis $(\mathrm{Pn})$, transpiration $(\mathrm{E})$ and stomatal conductance $\left(\mathrm{g}_{\mathrm{s}}\right)$ measured in cork oak trees.

\begin{tabular}{|c|c|c|c|}
\hline Treatment group & $\operatorname{Pn}\left(\mu \mathrm{mol} \mathrm{CO} \mathrm{CO}_{2} \mathrm{~m}^{-2} \mathrm{~s}^{-1}\right)$ & $\mathrm{E}\left(\mathrm{mmol} \mathrm{H} \mathrm{H}_{2} \mathrm{~m}^{-2} \mathrm{~s}^{-1}\right)$ & $\mathrm{g}_{\mathrm{s}}\left(\mathrm{mmol} \mathrm{H} \mathrm{H}_{2} \mathrm{~m}^{-2} \mathrm{~s}^{-1}\right)$ \\
\hline $\mathrm{DC}$ & $8.2 \pm 0.48 \mathrm{a}$ & $2.4 \pm 0.14 \mathrm{a}$ & $107.1 \pm 8.35 \mathrm{ab}$ \\
\hline $\mathrm{HC}$ & $7.8 \pm 0.84 a$ & $2.1 \pm 0.18 a$ & $89.5 \pm 9.64 a$ \\
\hline DNC & $8.3 \pm 0.33 a$ & $2.3 \pm 0.12 \mathrm{a}$ & $130.9 \pm 7.88 b c$ \\
\hline HNC & $9.9 \pm 0.26 b$ & $3.2 \pm 0.17 b$ & $155.5 \pm 13.59 c$ \\
\hline
\end{tabular}

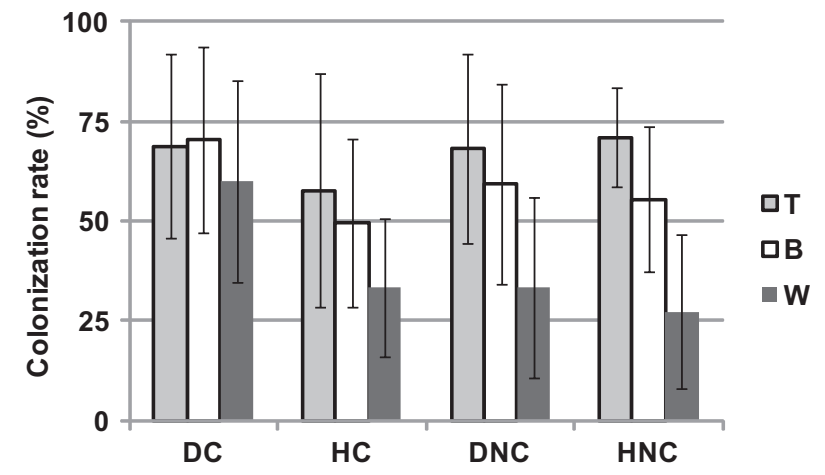

Fig. 4. Mean colonization rate of different cork oak tissues: twigs (T), branches (B) and trunk wood (W). DC, declining covered trees; HC, asymptomatic covered trees; DNC, declining control trees; HNC, asymptomatic control trees. Bars represent standard deviation.

Table 3. Endophytic colonization rate (CR), number of endophytic colonies, number of species isolated, Shannon diversity index and Simpson dominance index in the different sampling periods.

\begin{tabular}{|c|c|c|c|c|c|c|}
\hline Period & Treatment group & CR $(\%)^{*}$ & No. colonies & No. species & Shannon diversity index & Simpson dominance index \\
\hline \multirow[t]{4}{*}{ July 2003} & DC & $41.9 b-d$ & 36 & 7 & 1.34 & 0.41 \\
\hline & $\mathrm{HC}$ & $33.3 \mathrm{ab}$ & 28 & 11 & 1.73 & 0.31 \\
\hline & DNC & $44.4 \mathrm{~b}-\mathrm{e}$ & 38 & 9 & 1.66 & 0.28 \\
\hline & HNC & $40.7 \mathrm{a}-\mathrm{d}$ & 36 & 13 & 2.06 & 0.20 \\
\hline \multirow[t]{4}{*}{ October 2003} & DC & $49.4 \mathrm{c}-\mathrm{f}$ & 42 & 4 & 0.34 & 0.86 \\
\hline & $\mathrm{HC}$ & $27.2 \mathrm{a}$ & 24 & 5 & 0.87 & 0.58 \\
\hline & DNC & 48.1cde & 42 & 6 & 1.09 & 0.46 \\
\hline & HNC & $41.9 b-d$ & 38 & 5 & 0.96 & 0.49 \\
\hline \multirow{4}{*}{ February 2004} & DC & $88.9 \mathrm{i}$ & 78 & 7 & 0.75 & 0.68 \\
\hline & $\mathrm{HC}$ & $62.9 \mathrm{fg}$ & 57 & 11 & 1.70 & 0.31 \\
\hline & DNC & $80.2 \mathrm{hi}$ & 70 & 10 & 1.80 & 0.24 \\
\hline & HNC & $72.8 \mathrm{gh}$ & 63 & 13 & 2.16 & 0.17 \\
\hline \multirow[t]{4}{*}{ April 2004} & DC & $72.8 \mathrm{gh}$ & 62 & 9 & 0.97 & 0.61 \\
\hline & $\mathrm{HC}$ & $58.0 \mathrm{ef}$ & 51 & 15 & 2.16 & 0.20 \\
\hline & DNC & $39.5 \mathrm{abc}$ & 36 & 7 & 1.57 & 0.26 \\
\hline & HNC & 48.1cde & 43 & 12 & 2.03 & 0.19 \\
\hline \multirow[t]{4}{*}{ June 2004} & DC & 79.0hi & 66 & 5 & 0.60 & 0.73 \\
\hline & $\mathrm{HC}$ & $53.1 \mathrm{c}-\mathrm{f}$ & 47 & 12 & 1.83 & 0.25 \\
\hline & DNC & 55.6def & 49 & 12 & 1.91 & 0.23 \\
\hline & HNC & $53.1 \mathrm{c}-\mathrm{f}$ & 49 & 11 & 1.98 & 0.17 \\
\hline
\end{tabular}

Nineteen fungal endophytic species were isolated from the 1620 processed plant fragments; 18 were identified to species/genus level, one coelomycete could not be identified (Table 4).

Among the isolated fungi only B. mediterranea was detected in all examined trees and in each sampling period. The IF values of this xylariaceous fungus were always significantly higher in the declining covered trees than in other cork oak trees, with the exception of the first sampling (Table 4). The occurrence of this fungus in asymptomatic control trees was significantly higher 


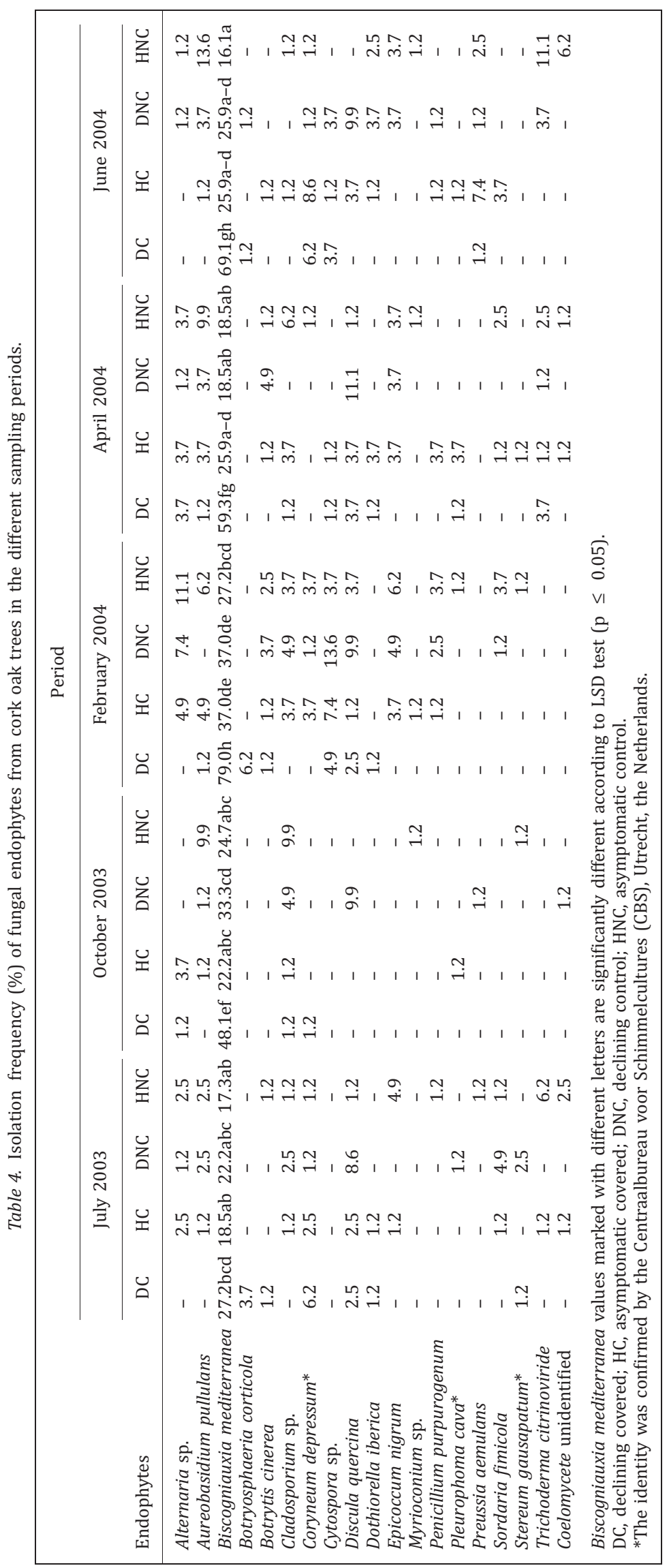


in winter (February 2004) than in summer (June 2004), showing clear seasonal patterns of endophyte infection. These results were similar to the findings obtained by Linaldeddu et al. (2005a) on the seasonal fluctuations of the colonization by $B$. mediterranea in a natural cork oak forest in Sardinia (Italy).

Remarkably, the occurrence of fungal species such as B. corticola, Coryneum depressum Kunze, Cytospora sp., D. quercina, $P$. cava and Stereum gausapatum (Fr. : Fr.), often reported as having weak pathogenic behaviour on Quercus spp. (Luisi et al. 1993; Muñoz et al. 1996; Franceschini et al. 2000; Luque et al. 2000), was detected (Table 4). However, all these species were isolated sporadically. B. corticola, the most virulent of these species (A. Franceschini and B. T. Linaldeddu, unpublished data), was detected mostly in February, and in the declining covered trees. Coryneum depressum was isolated more frequently from covered than from control trees. Discula quercina, the casual agent of oak anthracnose, canker and branch dieback on several oak species in Europe and northern America (Moricca and Ragazzi 2008), was isolated mainly from declining control trees.

In addition, several other fungal species were found which are well-known for their antagonistic behaviour against $B$. mediterranea, B. corticola and D. quercina (Linaldeddu et al. 2005b; Maddau et al. 2009), such as Epicoccum nigrum Link, Penicillium purpurogenum Stoll, Preussia aemulans (Rehm) Arx and Trichoderma citrinoviride Bissett. These species, despite having low values of IF, were mostly associated with asymptomatic control trees.

The ecological role of sporadically isolated endophytic fungi remains elusive; some species such as Aureobasidium pullulans (de Bary) G. Arnaud and Sordaria fimicola (Roberge ex Desm.) Ces. \& De Not. are frequently reported as endophytes of forest trees (Pugh and Buckley 1971; Collado et al. 1999).

\subsection{Endophytic community structure}

The mean number of endophytic species isolated tended to be higher in asymptomatic than in declining cork oak trees, and to be higher in control than covered trees (Table 3). The Shannon diversity reflected the strong impact of the drought treatment on the microbial community diversity both in asymptomatic and declining cork oak trees (Table 3). Diversity indices were higher in asymptomatic control trees than in covered asymptomatic trees. During the experimental period the Shannon diversity index clearly decreased from 1.34 in July 2003 to 0.6 in June 2004 in the declining covered trees. Moreover, the fungal endophytic community associated with declining covered trees is characterized by a high dominance index, as a result of the high incidence of $B$. mediterranea infections.

\section{Discussion}

In this study the drought effects on the diversity of endophytic fungal communities associated with cork oak were analyzed.

The cover treatment notably reduced the soil moisture content, simulating drought conditions. Leaf gas exchange was affected by an artificially induced reduction of soil moisture by plastic roofs. In particular, the rates of net photosynthesis, transpiration and stomatal conductance, measured more than 1 year after the treatment was started, were higher in the control treatment. The reduction of gas exchange in cork oak trees during water stress periods has already been reported by several authors (Faria et al. 1996; García-Plazaola et al. 1997), as a consequence of reduced stomatal conductance and physiological changes related to the activity of the enzymes of the antioxidant system. These mechanisms allow cork oak to optimize the use of carbon and water resources during periods of limited water availability occurring in summer in the Mediterranean areas. The PWP values recorded throughout the whole experimental period confirm the efficiency of the plastic covers in reducing water availability; this was more evident after the summer of 2003, when the mean soil moisture difference between covered and control trees was higher than during the other periods. The lower water availability in covered trees seems to have induced a progressive qualitative and quantitative shift in the endophytic fungi associated with cork oak trees. The qualitative change in endophytic fungal community assemblages on oak trees during water stress periods has already been reported by Gonthier et al. (2006). The endophytic lifestyle has been described as a balanced antagonism between fungus and host plant (Schulz et al. 1999; Schulz and Boyle 2005). Thus, it is possible that water stress may have altered the plant defence of covered cork oak trees against some endophytic species, in particular B. mediterranea. The endophytic occurrence of this pathogen in declining covered trees was copious also in trunk wood tissues (data not shown). This result emphasizes that water stress induces $B$. mediterranea to switch from the latent to the pathogenic phase. The pathogenic behaviour of $B$. mediterranea on several Mediterranean oak species is frequently associated with severe water stress (Vannini et al. 1996, 2009; Luque et al. 2000; Capretti and Battisti 2007). The seasonal variation of B. mediterranea infections in cork oak trees recognized in this study concords with the data previously reported by Collado et al. (1999) on holm oak in Spain. Among the other opportunistic pathogens, $C$. depressum has been detected most frequently in declining covered trees suggesting a possible involvement of this fungus in cork oak decline. Coryneum spp. are often referred to as having weak pathogenic behaviour on severely water stressed hosts (Luque et al. 2000).

Water stress, besides favouring the endophytic infections of some opportunistic fungal pathogens, and causing a reduction in cork oak endophytic microbial biodiversity, seems to negatively influence the endophytic proliferation of some antagonistic fungal species. For example, T. citrinoviride was rarely detected in covered compared to control trees. This endophytic Trichoderma species is characterized by a strong antagonistic activity against the main pathogens involved in oak decline (Linaldeddu et al. 2005b, 2007b). Recently, the endophytic strain of T. citrinoviride from cork oak has been shown to produce a mixture of polypeptide antibiotics (peptaibols) in liquid culture. These antibiotics belong to the paracelsin family and showed a strong antifungal activity against seven dangerous forest tree pathogens (Maddau et al. 2009). Thus, the knowledge of plantassociated fungi and their antagonistic potential is essential not only to understand their ecological role, but also for future biotechnological applications in agriculture and forestry. 
Finally, our results contribute to improving the knowledge of the cryptic presence of endophytic fungi in different tissues of cork oak trees, and demonstrate that the incidence of some fungal endophytes, mainly B. mediterranea, is linked to host phenology, and to changes in plant physiology caused by prolonged drought periods.

\section{Acknowledgements}

This research was supported by the MIUR project 'Role of endophytic fungi in oak decline'.

\section{References}

Anselmi, N.; Cellerino, G. P.; Franceschini, A.; Granata, G.; Luisi, N.; Marras, F.; Mazzaglia, A.; Mutto Accordi, S.; Ragazzi, A., 2004: Geographic distribution of fungal endophytes of Quercus sp. in Italy. In: Endophytism in Forest Trees. Ed. by Ragazzi, A.; Moricca, S.; Dellavalle, I. Firenze: Accademia Italiana di Scienze Forestali, pp. 73-89.

Bakry, M.; Abourouh, M., 1995: Dépérissement du chêne-liège au Maroc: état des connaissances et perspectives. IOBC/WPRS Bull. 18, 50-55.

Boerema, G. H.; de Gruyter, J.; Noordeloos, M. E.; Hamers, M. E. C., 2004: Phoma Identification Manual. Differentiation of Specific and Intraspecific Taxa in Culture. Wallingford, UK: CABI Publishing.

Boyer, J. S., 1995: Biochemical and biophysical aspects of water deficits and the predisposition to disease. Annu. Rev. Phytopathol. 33, $251-274$.

Bradford, J.; Hsiao, T. C., 1982: Physiological responses to moderate water stress. In: Encyclopaedia of Plant Physiology 12B. Water Relations and Carbon Assimilation. Physiological Plant Ecology II. Ed. by Lange, O. L.; Nobel, P. S.; Osmond, C. B.; Ziegler, H. Berlin: Springer-Verlag, pp. 263-324.

Capretti, P.; Battisti, A., 2007: Water stress and insect defoliation promote the colonization of Quercus cerris by the fungus Biscogniauxia mediterranea. For. Pathol. 37, 129-135.

Carroll, G. C., 1988: Fungal endophytes in stems and leaves: from latent pathogen to mutualistic symbiont. Ecology 69, 2-9.

Cavender-Bares, J., 2007: Chilling and freezing stress in live oaks (Quercus section Virentes): intra- and inter-specific variation in PSII sensitivity corresponds to latitude of origin. Photosynth. Res. 94, 437-453.

Collado, J.; Platas, G.; González, I.; Peláez, F., 1999: Geographical and seasonal influences on the distribution of fungal endophytes in Quercus ilex. New Phytol. 144, 525-532.

Cowling, R. M.; Ojeda, F.; Lamont, B. B.; Rundel, P. W.; Lechmere-Oertel, R., 2005: Rainfall reliability, a neglected factor in explaining convergence and divergence of plant traits in fire-prone Mediterranean-climate ecosystems. Glob. Ecol. Biogeogr. 14, 509-519.

David, T. S.; Cabral, M. T.; Sardinha, R. M. A., 1992: A mortalidade dos sobreiros e a seca. Finisterra 27, 17-24.

Desprez-Loustau, M. L.; Marcais, B.; Nageleisen, L. M.; Piou, D.; Vannini, A., 2006: Interactive effects of drought and pathogens in forest trees. Ann. For. Sci. 63, 597-612.

Ellis, M. B.; Ellis, J. P., 1997: Microfungi on Land Plant. An Identification Handbook. England: Richmond Publishing.

Faria, T.; Garcia-Plazaola, J. I.; Abadia, A.; Cerasoli, S.; Pereira, J. S.; Chaves, M. M., 1996: Diurnal changes in photoprotective mechanisms in leaves of cork oak (Quercus suber) during summer. Tree Physiol. 16, 115-123.

Franceschini, A.; Corda, P.; Marras, F., 2000: Fungi involved in oak decline. In: Decline of Oak Species in Italy; Problems and Perspectives. Ed. by Ragazzi, A.; Dellavalle, I. Firenze: Accademia Italiana di Scienze Forestali, pp. 99-113.

Franceschini, A.; Linaldeddu, B. T.; Marras, F., 2005: Occurrence and distribution of fungal endophytes in declining cork oak forests in Sardinia (Italy). IOBC/WPRS Bull. 28, 67-74.

Gallego, F. J.; Perez de Algaba, A.; Fernandez-Escobar, R., 1999: Etiology of oak decline in Spain. Eur. J. Forest Pathol. $29,17-27$.

García-Plazaola, J. I.; Faria, T.; Abadia, J.; Abadia, A.; Chaves, M. M.; Pereira, J. S., 1997: Seasonal changes in xanthophyll composition and photosynthesis of cork oak (Quercus suber L.) leaves under Mediterranean climate. J. Exp. Bot. 48, 1667-1674.

Garrett, K. A.; Dendy, S. P.; Frank, E. E.; Rouse, M. N.; Trave, S. E., 2006: Climate change effects on plant disease: genomes to ecosystems. Annu. Rev. Phytopathol. 44, 489-509.

Gonthier, P.; Gennaro, M.; Nicolotti, G., 2006: Effects of water stress on the endophytic mycota of Quercus robur. Fungal Divers. 21, 69-80.

Hammer, Ø.; Harper, D. A. T.; Ryan, P. D., 2001: PAST: Paleontological Statistics Software Package for education and data analysis. Palaeontol. Electronica 4, 9.

Kozlowski, T. T.; Pallardy, S. G., 2002: Acclimation and adaptive responses of woody plants to environmental stresses. Bot. Rev. 68, 270-334.

Larcher, W., 2000: Temperature stress and survival ability of Mediterranean sclerophyllous plants. Plant Biosyst. 134, $279-295$.

Linaldeddu, B. T.; Franceschini, A.; Pulina, M. A., 2005a: Epidemiological aspects of Biscogniauxia mediterranea in declining cork oak forest in Sardinia (Italy). IOBC/WPRS Bull. 28, 75-81.

Linaldeddu, B. T.; Maddau, L.; Franceschini, A., 2005b: Preliminary in vitro investigation on the interaction among endophytic fungi isolated from Quercus spp. IOBC/WPRS Bull. 28, 101-102.

Linaldeddu, B. T.; Franceschini, A.; Luque, J.; Phillips, A. J. L., 2007a: First report of canker disease caused by Botryosphaeria parva on cork oak trees in Italy. Plant Dis. 91, 324.

Linaldeddu, B. T.; Maddau, L.; Franceschini, A., 2007b: Attività antagonistica di isolati endofitici di Trichoderma spp. verso Botryosphaeriaceae associate al deperimento della quercia da sughero. Micol. Ital. 36, 22-29.

Linaldeddu, B. T.; Sirca, C.; Spano, D.; Franceschini, A., 2009: Physiological responses of cork oak and holm oak to infection by fungal pathogens involved in oak decline. For. Pathol. 39, 232-238.

Luisi, N.; Manicone, R. P.; Sicoli, G.; Lerario, P., 1993: Pathogenicity tests of fungi associated with oak decline on Quercus spp. seedlings grown at different water regimes. In: Recent Advances in Studies on Oak Decline. Ed. by Luisi, N.; Lerario, P.; Vannini, A. Putignano, Italy: Tipolitografia Radio, pp. 85-93.

Luque, J.; Girbal, J., 1989: Dieback of cork oak (Quercus suber) in Catalonia (NE Spain) caused by Botryosphaeria stevensii. Eur. J. Forest Pathol. 19, 7-13.

Luque, J.; Cohen, M.; Savé, R.; Biel, C.; Álvarez, I. F., 1999: Effects of three fungal pathogens on water relations, chlorophyll fluorescence and growth of Quercus suber L. Ann. For. Sci. 56, 19-26.

Luque, J.; Parladé, J.; Pera, J., 2000: Pathogenicity of fungi isolated from Quercus suber in Catalonia (NE Spain). For. Pathol. 30, $247-263$.

Maddau, L.; Cabras, A.; Franceschini, A.; Linaldeddu, B. T.; Crobu, S.; Roggio, T.; Pagnozzi, D., 2009: Occurrence and characterization of peptaibols from Trichoderma citrinoviride, an endophytic fungus of cork oak, using electrospray ionization quadrupole time-of-flight mass spectrometry. Microbiology 155, 3371-3381.

Moricca, S.; Ragazzi, A., 2008: Fungal endophytes in Mediterranean oak forests: a lesson from Discula quercina. Phytopathology 98, 380-386. 
Mucciarelli, M.; Scannerini, S.; Bertea, C.; Maffei, M., 2003: In vitro and in vivo peppermint (Mentha piperita) growth promotion by nonmycorrhizal fungal colonization. New Phytol. 158, 579-591.

Muñoz, M. C.; Cobos, P.; Martínez, G.; Soldevilla, C.; Díaz, M., 1996: Micoflora y patología del alcornoque (Quercus suber L.) Madrid, Spain: Ministerio de Agricultura, Pesca y Alimentación.

Novillo, F.; Alonso, J. M.; Ecker, J. E.; Salinas, J., 2004: CBF2/DREB1C is a negative regulator of CBF1/DREB1B and CBF3/DREB1A expression and plays a central role in stress tolerance in Arabidopsis. Proc. Natl. Acad. Sci. 101, 3985-3990.

Oliveira, G.; Penuelas, J., 2004: Effects of winter cold stress on photosynthesis and photochemical efficiency of PSII of the Mediterranean Cistus albidus L. and Quercus ilex L. Plant Ecol. 175, 179-191.

Oliveira, G.; Correia, O. A.; Martins-Loucão, M. A.; Catarino, F. M., 1992: Water relations of cork-oak (Quercus suber L.) under natural conditions. Vegetatio 99-100, 199-208.

Otieno, D. O.; Schmidt, M. W. T.; Kurz-Besson, C.; Lobo Do Vale, R.; Pereira, J. S.; Tenhunen, J. D., 2007: Regulation of transpirational water loss in Quercus suber trees in a Mediterranean-type ecosystem. Tree Physiol. 27, 1179-1187.

Phillips, A. J. L.; Alves, A.; Correia, A.; Luque, J., 2005: Two new species of Botryosphaeria with brown, 1-septate ascospores and Dothiorella anamorphs. Mycologia 97, 513-529.

Pitt, J. I., 1991: A Laboratory Guide To Common Penicillium species. North Ryde, New South Wales, Australia: Commonwealth Scientific and Industrial Research Organization, Division of Food Processing.

Pugh, G. J. F.; Buckley, N. G., 1971: Aureobasidium pullulans: an endophyte in sycamore and other trees. Trans. Br. Mycol. Soc. 57, $227-231$.

Ragazzi, A.; Moricca, S.; Capretti, P.; Dellavalle, I.; Turco, E., 2003: Differences in composition of endophytic mycobiota in twigs and leaves of healthy and declining Quercus species in Italy. For. Pathol. 33, 31-38.

Redman, R. S.; Dunigan, D. D.; Rodriguez, R. J., 2001: Fungal symbiosis from mutualism to parasitism: who controls the outcome, host or invader? New Phytol. 151, 705-716.

Sánchez, M. E.; Venegas, J.; Romero, M. A.; Phillips, A. J. L.; Trapero, A., 2003: Botryosphaeria and related taxa causing oak canker in southwestern Spain. Plant Dis. 87, 1515-1521.

Sánchez-Gómez, D.; Valladares, F.; Zavala, M. A., 2006: Performance of seedlings of Mediterranean woody species under experimental gradients of irradiance and water availability availability: trade-offs and evidence for niche differentiation. New Phytol. 170, $795-806$.

Santos, M. N. S., 1995: Phytopathological situation of cork oak (Quercus suber L.) in Portugal. IOBC/WPRS Bull. 18, 38-42.

Schoeneweiss, D. F., 1975: Predisposition, stress, and plant disease. Annu. Rev. Phytopathol. 13, 193-211.

Schulz, B.; Boyle, C., 2005: The endophytic continuum. Mycol. Res. 109, 661-686.

Schulz, B.; Rommert, A. K.; Dammann, U.; Aust, H. J.; Strack, D., 1999: The endophyte-host interaction: a balanced antagonism?. Mycol. Res. 103, $1275-1283$.

Sieber, T. N., 2007: Endophytic fungi in forest trees: are they mutualists? Fungal Biol. Rev. 21, 75-89.

Slippers, B.; Wingfield, M. J., 2007: Botryosphaeriaceae species as endophytes and latent pathogens of woody plants: diversity, ecology and impact. Fungal Biol. Rev. 21, 90-106.

Suping, Z.; Sauvé, R. J.; Mmbaga, M. T., 2005: Adaptation of Pachysandra terminalis Sieb. \& Zucc. to freezing temperatures by the accumulation of mRNA and cold-induced proteins. HortScience 40, 346-347.

Sutton, B. C., 1980: The Coelomycetes. Fungi imperfecti with Pycnidia, Acervuli and Stromata. Kew, Surrey: Commonwealth Mycological Institute.

Tenhunen, J. D.; Lange, O. L.; Gebel, J.; Beyschlag, W.; Weber, J. A., 1984: Changes in photosynthetic capacity, carboxylation efficiency, and $\mathrm{CO}_{2}$ compensation point associated with midday stomatal closure and midday depression of net $\mathrm{CO}_{2}$ exchange of leaves of Quercus suber. Planta 162, 193-203.

Vannini, A.; Luisi, N.; Valentini, R., 1996: Impact of drought and Hypoxylon mediterraneum on oak decline in the Mediterranean region. Ann. For. Sci. 53, 753-760.

Vannini, A.; Lucero, G.; Anselmi, N.; Vettraino, A. M., 2009: Response of endophytic Biscogniauxia mediterranea to variation in leaf water potential of Quercus cerris. For. Pathol. 39, 8-14.

Varone, L.; Gratani, L., 2007: Physiological response of eight Mediterranean maquis species to low air temperatures during winter Photosynthetica 45, 385-391.

Wang, W.; Vinocur, B.; Shoseyov, O.; Altman, A., 2004: Role of plant heat-shock proteins and molecular chaperones in the abiotic stress response. Trends Plant Sci. 9, 244-252. 